Девляшова Любовь Николаевна

студентка

Жуйкова Тамара Павловна

канд. пед. наук, доцент

Институт непрерывного

педагогического образования

ФГБОУ ВО «Хакасский государственный

университет им. Н.Ф. Катанова»

г. Абакан, Республика Хакасия

DOI $10.21661 / r-462549$

ИСПОЛЬЗОВАНИЕ ЛОГИЧЕСКИХ ЗАДАНИЙ

В РАЗВИТИИ МАТЕМАТИЧЕСКИХ СПОСОБНОСТЕЙ

\title{
У ДЕТЕЙ СТАРШЕГО ДОШКОЛЬНОГО ВОЗРАСТА
}

Аннотация: в данной статье исследованы основные аспекты понятия «математические способности». Перечислены компоненты математических способностей. Рассмотрены основные формы организащии занятий, применяемые в работе с детьми, при использовании логических упражнений и заданий. Отмечена важность формирования и развития математических способностей у дошкольников.

Ключевые слова: математика, математические способности, занятия, дети.

С каждым годом математика находит все более широкое и разнообразное применение в областях человеческой деятельности. Как указывает академик А.Н. Колмогоров «принципиально область математики не ограничена» [2, с. 33]. При рассмотрении понятия «математические способности», нами было установлено, что оно является многогранным, сложным и комплексным. То есть данное понятие включает в себя множество взаимосвязанных представлений: о форме, пространстве, величине времени и т. д. Помимо этого в математические 
способности включены и различные научные и житейские понятия, которые необходимы для формирования ребенка.

Как известно довольно части дети в начальной школе испытывают различного рода трудности в области изучения математики. Одной из причин можно назвать потерю интереса к математике как к предмету.

Отсюда следует, что одной из наиболее важных задач педагогов и родителей является развить у ребенка с малых лет любовь и уважение к математике. Приобщение к математике необходимо осуществлять не навязчиво, учитывая, что основным видом деятельности ребенка дошкольного возраста является игра, именно в игровой форме и нужно прививать любовь к математике. В различных играх с математическим уклоном ребенок приобщается к математике, у него появляется к ней как к науке уважение и интерес. Все это способствует тому, что при поступлении в школу, ребенок не просто имеет представление о математике как о науке, а оперирует основными математическими определениями, ему легче усваивать программу, нет того страха, который проявляют большинство детей младшего дошкольного возраста перед уроками математики.

Математическая способность - это довольно сложное структурированное психическое образование, представляющее собой своеобразный синтез определенных параметров, которые охватывают все стороны математической деятельности.

Математические способности являются прижизненными, то есть приобретенными в процессе жизни, полученные во время обучения, они не являются врожденными. Все это говорит о том, что математические способности необходимо развивать.

Крутецкий В.А. различает девять способностей (компонентов математических способностей) [2, с. 118-119]:

Способность к формализации математического материала. Эта способность выражается в умении отделять форму от содержания, абстрагированию от опре- 
деленных количественных взаимоотношений и пространственных форм и оперированию формальными структурами, структурами взаимоотношений и взаимосвязей.

Способность обобщать материалы в единое целое по определенным признакам, уметь вычленять основное, абстрагироваться от несущественного, видеть общее в разных предметах и материалах.

Способность к оперированию числовой и знаковой символикой.

Способность верно и логично рассуждать, выстраивать ход своих мыслей структурировано, полученные в ходе рассуждения выводы аргументировать, подтверждать, правильно подводить итоги и выводы.

Способность в процессе размышления так выстроить процесс, чтобы в итоге он был строго по конкретному предмету, без лишних операций и потерь времени в работе.

Способность к обратимости мыслительного процесса (к переходу с прямого на обратный ход идеи).

Гибкость мышления. Выражается в том, что ребенок умеет в процессе рассуждения переходить от одной мысли к другой, при этом он быстро переключается и вникает в новый процесс легко. Рассуждает и размышляет не стандартно, без использования шаблонов и иных стандартных форм.

Математическая память. Можно допустить, что ее отличительные особенности также вытекают из особенностей математической науки, что это память на обобщения, формализованные структуры, закономерные схемы.

Способность к пространственным представлениям, которая прямым образом связана с наличием таковой ветви математики как геометрия.

Как уже было сказано выше, математические способности не даются каждому от рождения их необходимо развивать. Развитию математических способностей благоприятствует специально созданная среда и условия. Необходимо как можно раньше начинать занятия с ребенком, нельзя упускать сензитивный период развития ребенка, в котором он наиболее восприимчив к новому. Если 
данный период будет упущен, то в дальнейшем пробел будет сложно заполнить, и мы обрекаем ребенка на медленное развитие.

Основные формы организации, которые могут быть использованы в работе с детьми, при использовании логических упражнений и заданий:

Занятия (комплексные, интегрированные), обеспечивающие наглядность, системность и доступность, смену деятельности. На занятиях используются логические задания, представленные выше. Занятия проводились с детьми групповые и индивидуальные.

Совместная и самостоятельная игровая деятельность (дидактические игры, настольно - печатные, подвижные, сюжетно - ролевые игры).

Вне занятий. Работа в кружке «Геометрическая мозаика», где также были использованы логические задания.

Занятия, с использованием логических блоков, способствуют не только изучению нового материла на занятиях, но и способствуют закреплению уже пройденного.

При знакомстве с геометрическими фигурами предлагаются такие занятия: «Путешествие в город геометрических фигур», «Путешествие по стране «Смекалочка», «Увлекательное путешествие по сказке «Маша и Медведь» с использованием игровых упражнений с блоками Дьенеша», «Сказочное путешествие с Иваном-Царевичем за тридевять земель», «Страна Математика» и др. [3].

Таким образом, активное внедрение логических упражнений и заданий обусловило математизацию разных видов деятельности. Это говорит о том, что математическое развитие детей невозможно в отсутствии включения в обучающий процесс логических задач. Они являются действенным средством становления и формирования математических способностей. 


\section{Список литературы}

1. Крутецкий В.А. Психология математических способностей дошкольников / В.А. Крутецкий. - М., 1968. - 475 с.

2. Математика - наука и профессия / А.Н. Колмогоров. $-1988 .-618$ с.

3. Смоленцева А.А. Сюжетно-дидактические игры с математическим содержанием / А.А. Смоленцева. - М., 2007. - 128 с. 